\title{
LEGAL DEVELOPMENT BASED ON LOCAL WISDOM AS THE BASIS OF A SETTINGS FOR RELIGIOUS LIFE IN CENTRAL JAVA ${ }^{\Omega}$
}

\author{
Rini Fidiyani and Baidhowi \\ Law Faculty of Semarang State University \\ E-mail: fidiyani.rini@gmail.com
}

\begin{abstract}
The constitution guarantees freedom of religious life in Indonesia. This guarantee is becoming a myth that is caused by the inability of the state or its agents in fulfilling the promises of its constitution. Religious life in Central Java that seems comfortable but it seems to keep fire. This study is a qualitative research with anthropology, ethnography and law approach. The results shows that the religious conflicts that occurred in Central Java, is because the inappropiate view of the religious exclusivism and the decreasing local wisdom in daily life. Though Central Java have local wisdom which can be used as material development of laws in conflict resolution. But there is a juridical obstacles in its development, because of the unsynchron between the law relating to local authorities in making policy of inter-religious conflict resolution. Therefore, the development of laws based on local wisdom can be done if the juridical obstacles is overcome first.
\end{abstract}

Keywords: freedom of religion, local wisdom, exclusivism, inclusivism, juridical obstacles, social conflict.

\begin{abstract}
Abstrak
Konstitusi telah memberikan jaminan kebebasan kehidupan beragam di Indonesia. Jaminan ini lamalama menjadi mitos yang disebabkan oleh ketidakmampuan negara atau aparatnya dalam memenuhi janji-janji konstitusinya. Kehidupan keagamaan di Jawa Tengah yang kelihatannya nyaman ternyata menyimpan bara. Penelitian ini merupakan penelitian kualitatif dengan metode pendekatan dari antropologi, etnografi dan hukum. Hasil penelitian menunjukkan bahwa konflik antar umat beragama yang terjadi di Jawa Tengah, berakar pada penempatan pandangan eksklusivisme agama yang tidak tepat dan lunturnya nilai-nilai kearifan lokal dalam hidup sehari-hari. Padahal Jawa Tengah memiliki kearifan lokal yang dapat dijadikan sebagai bahan pengembangan hukum dalam penyelesaian konflik. Akan tetapi ada kendala yuridis dalam pengembangan hukum tersebut, karena adanya ketidaksinkronan antara perundang-undangan yang berkaitan dengan wewenang daerah dalam membuat kebijakan penyelesaian konflik antar umat beragama. Oleh karena itu, pengembangan hukum berbasis kearifan lokal dapat dilakukan apabila kendala yuridis ini diatasi terlebih dahulu.
\end{abstract}

Kata kunci : kebebasan beragama, kearifan lokal, eksklusivisme, inklusivisme, kendala yuridis, konflik sosial.

\section{Introduction}

As common country in the world moreover which is determined as a legal state, ${ }^{1}$ the

$\Omega \quad$ This article is a result of National Research Strategy skim, which conducted based on Letter of Agreement National Implementation Research Grants for Lecturers of Private Higher Education Batch I UNNES 2015 Number: 523/UN37.3.1/LT/2015

Clarification of Legal State can be read on B. Arief Sidharta, "Kajian Kefilsafatan tentang Negara Hukum", Jurnal Hukum "JENTERA", $3^{\text {rd }}$ Edition of $2^{\text {nd }}$ Year, November 2004; and Marjanne Termorshuizen, "The Concept Rule of Law", Jurnal Hukum "JENTERA", Edisi $3^{\text {rd }}$ Edition of $2^{\text {nd }}$ Year, November 2004. promises to the citizens are poured into the state constitution. Indonesia put the promises which is also called sacred promise - in the 1945 Constitution. It is not without a cause if this paper begins with a skeptical tone as it is, this happens because of the promise of the state to its citizens sometimes more than a nonsense, either because of the inability of the state or omissions of its agents in fulfilling its obligations. If it is so, then the neat row promi- 
ses as the articles of the constitution is nothing more than a myth.

One of the example of this - and the subject of this article - is the promise of the state as poured in Article 29 paragraph (2) of the 1945 Constitution (the first phrase) to guarantee the independence of each citizen to have a religion. This promise is reinforced by the provisions of Article 28E (1) and (2) of the 1945 Constitution in conjunction with Article 22 paragraph (1) of Law No. 39 of 1999 on Human Rights (HAM). This promise is not a promise to give freedom, because it contains certain restrictions on some religion which is determined by the state to its citizens to choose one of the specified religion. This is the promise that eventually became the first myth.

One thing noted from the state constitution in matters of religious freedom is the inconsistency between chapter one to another. It is Article 28 paragraph (1) jo jo Article 4 of the Human Rights Act, which specifies that the freedom of religion is one of the rights that can not be reduced under any circumstances. The phrase "can not be reduced under any circumstances" indicate that the guarantee of the state for the implementation of this right has a high position. However, it is then restricted by the provisions of Article 28J paragraph (1) and (2) which determines the duty of every person to respect other people's rights in persons and the restrictions prescribed by law. There are two paradoxes in this case, first, the constitution on one side gives freedom, but on the other side limit the freedom, then what is the meaning of the phrase "can not be reduced under any circumstances"; second, if the constitution gives freedom and laws limit it, does it not violate the legal principle of lex superiori derogat legi inferiori. This is the second myth that make the promise of the state become a serious problem in the practice of religious life.

The third myth which is relates to the events in the community is related to Article 28 paragraph (2), where state guarantees every person (as the right) free from discriminatory treatment on any basis and the right of protec- tion against discriminatory treatment. This Article relates to Article 29 paragraph (2) second phrase, namely the freedom to worship according to citizens religion and beliefs. That provision is said to be a myth because until now - in many cases - the state has failed to provide protection to its citizens in implementing the freedom of religion.

This third myth is the one that will be the topic of discussion in this article, with the setting case in Central Java. Choosing Central Java as the place is not without reason, because in the past, this area has a bitter experience related to the violence with religious as the background itself. Generally the religious life conditions in Central Java is relative safe, however doesn't mean its without turmoil. The turmoil still remain, but the escalation level is not that high. In addition to this, the Central Java which are largely populated by Javanese people actually have a cultural values or local wisdom that can be relied upon in building a harmonious life. The question is, where are these values when the conflicts between religious communities happens.

\section{Problems}

There are three problems discussed in this article, namely: first, the identification of a case or conflicts between religious community in Central Java along with the research to the root of the problem; secondly, the identification of local wisdom that can be used as material development of laws, where these laws can be used later as a means to resolve conflict and create a harmonious life; and third is to overcome constraints of judicial development of the law based on local wisdom.

\section{Research Method}

This study is a qualitative research with approach of ethnography and law anthropology. The Sources of the data in this study are human with their behavior, events, documents, archives and other objects. But the primary source of data in this study are the words and actions, the rest is additional data such as documents 
and others. Data collected by interactive and non-interactive methods, which are analyzed using an interactive model.

\section{Discussions}

Conflict and Roots of Problem in the Life between Religious Community in Central Java

In general, freedom of religion in Central Java just looked calm and warm, almost without tension, but if there was an explosion of events, the echo and the consequences can damage the public facilities, organization, or private property with a loss that can not be calculated definitely. As the report by the Institute for Social Studies and Religion (eLSA) Semarang in 2014, the religious situation in 2014 and 2015 show undifferent tendency to 2013. this does not mean that there is no conflict at all, but the conflict is local with low escalation level. The conflict occurs more frequently among elements of society, the conflict that led to the settlement through the courts is not much, and can generally be resolved by forum.

Here is the dynamics of religious life overview in Central Java. First, the refusal of Habib Riziq Shihab arrival, the chairman of the Islamic Defenders Front (FPI) on May 8, 2014 when he was about to attend the recitals in the district Bonang, Demak because Habib Abdurrahman Riziq is often insulting Gus Dur and his sermons has a little provocative content of tend to be so prone to trigger a conflict, but that area is a base of ahlussunah wal Jama'ah. Second, there is a series of arrests of terrorist suspects in Klaten on May 14-15, 2014 and December 2014 which indicate that Central Java became terrorist bases affiliated with one particular religion. Third, the ban of Sholat Jumat for Muslims of Terang Bangsa high school students. This ban triggered reactions in various elements. ${ }^{2}$ These figures show that Central Java has a fairly dynamics despite not having a high rank of the escalation, except for terrorism.

Look at Lembaga Studi Sosial dan Agama (eLSA), 2014, Laporan Kebebasan Beragama dan Berkeyakinan di Jawa Tengah Tahun 2014, Semarang: eLSA, page 33-35
The general overviews of violations toward religious freedom in Central Java can be described as follows. First, on March 11, 2014 there is a misunderstanding that was triggered by a letter from the Head of Grobogan to the leadership of Al-Quraan Semaan Jantiko Mantab Dzikrul Ghofilin (JMDG) Kiai Ahmad Mujib. But the content of the letter get protests because of the way calling JMDG Jamaah is disturbing the residents. Through the audiences between Jemaah JMDG, Member of Commission A DPRD Grobogan Regency And Head of Grobogan, this matter can be resolved. Second, December 2014, in the village of Siandong, district Larangan, Brebes Regency, there is discrimination in terms of the burial. The bodies can not be buried in the village cemetery because he is a follower of Sapto Darmo cult. The village leader and village elders explained that the TPU is only meant for Muslims only. Such an event is also happening in other region, such as Banyumas and Purbalingga. Third, Christmas celebration 2014 for the congregation of the Evangelical Church of Java Land (GITJ) in Dermolo village, subdistrict Kembang, district Jepara really be a bitter gift that is failed to carry out their religious ceremony. This happens because the officers did not give permission of celebration in the courtyard of the church, and the actual main reason is because the license for establishing the church has not come out, even though it has been three years of processing.

Other events in the form intolerance that is carried out by individuals, groups and even the government. Some of it which are presented below can be classified as acts of intolerance by relying on secondary data is as follows. First, in January 2014, a temple in Hamlet Giriloka, Girimarga village, district, Miri, Sragen Regency, being targeted for destruction by strangers, some statues were vandalized, unfortunately until now the suspect is still unknown. Second, on January 19, 2014 there is a study conducted by Shihabudin (FPI Chairman of Central Java), Caregiver of Pesantren Al Hadith Wonoboyo Temanggung. The content of the study is rated provocative that led to the 
destruction of the car. Third, the case involving the congregation of Majelis Tafsir Al Quran with residents in Demak. Residents assess this study is closed, exclusive and disrupting the lives of residents. Parties indicated there are congregations who incited citizens to conduct a dissolution, but residents argue that the recitation by this assembly disrupt the activities of people. ${ }^{3}$ Some other cases that often come to the surface is the establishment of a public school supported by a foundation affiliated with a particular religion suspected of religious activities besides managing the school. In addition, rife cases is the rejection of establishment of houses of worship.

Whether religion can be regarded as a source of conflict. This is the question that is in the minds of everyone when a conflict arises between religious communities. Nearly all religions teach the virtues that lead to peace and happiness. All religions believe in the truth of their own religion, and consider the views of other religions are less. This is the real main causes of the conflict. ${ }^{4}$ This view is called exclusivism. This view is based on a truth claim in every religion. Actually, such a claim is a necessity that should and need to be well embedded in every religious community. At this level,

\footnotetext{
Ibid, page $42-56$

A multicultural citizen of Indonesia has variety main conflict and to know that main conflict, read Usman Pelly, "Akar Kerusuhan Etnik di Indonesia: Suatu Kajian Awal Konflik dan DisintegrasiNasional di Era Reformasi”, Jurnal Antropologi Indonesia, Year XXI No. 581999. Jakarta: Anthropology Department of FISIP UI Cooperate with Yayasan Obor Indonesia; Parsudi Suparlan, "Konflik Sosial dan Alternatif Pemecahannya", Jurnal Antropologi Indonesia, Year XXII No. 59 1999. Jakarta: Anthropology Department of FISIP UI Cooperate with Yayasan Obor Indonesia; Syarif I. Igadrie, "Konflik Etnis di Ambon dan Sambas: Suatu Tinjauan Sosiologis", Jurnal Antropologi Indonesia, Year XXXI. No. 58 2002, Jakarta: Anthropology Department of FISIP UI Cooperate with Yayasan Obor Indonesia; Kathryn Robinson, “Ketegangan Antar Etnis, Orang Bugis dan Masalah 'Penjelasan”, Jurnal Antropologi Indonesia, Year XXIV No. 63, September-December 2000, Jakarta: Anthropology Department of FISIP UI Cooperate with Yayasan Obor Indonesia; Parsudi Suparlan, "Mayarakat Majemuk dan Perawatannya”, Jurnal Antropologi Indonesia, No. 63 Year XXIV, September-December, 2000, Jakarta: Anthropology Department of FISIP UI Cooperate with Yayasan Obor Indonesia.
}

the exclusivism is a belief of the its own context in internal of religions. ${ }^{5}$

Exclusivism has formed a religious ideology that is not capable of developing a culture of dialogue and tolerance. Not only in interreligious contexts, but also the intrareligious context it has become an obstacle of its own. In this case, inclusiveness is absolutely necessary, is an concept which assumes that the truth is not only found in the group itself, but also on other groups, including religious communities. It departs from the conviction that every religion preaches salvation. The substance of the religions are the same, but the way they teach and the Shari'a is different. That is the sunna of God, which no one is able to change it. ${ }^{6}$

Inclusivism is not an instant concept, because since the beginning of this has the character of an open, then inclusiveness needs rational and continuous interpretation to religious doctrine. According to Raimundo Panikkar, interpretations of religious texts are not only intended to have relevance to other different parties, but also makes its view to be accepted by the other party. ${ }^{7}$ Here, inclusiveness is a sociological necessity, which is the understanding of the other party does not rely solely on those aspects that exist in their communities, but rather try to understand things that are existed in another communities. Despite can not be denied, that when understand another community must have a strong foothold, concerning the possibility of common ground in the various differences and diversity. Therefore, inclusiveness is a dynamic process to assess internal and external treasures of the deepest in the universe. ${ }^{8}$

\section{Local Wisdom as Base of Legal Development}

Religious conflicts that are occur - both in Central Java and in other parts of Indonesia essentially rooted in two things. First, the ex-

5 Zuhairi Misrawi, 2010, Al-Qur'an Kitab Toleransi, Tafsir Tematik Islam Rahmatanlil'Alamin, Jakarta: Pustaka Oasis, page 176

6 Ibid, page 177-178

7 Raimondo Pannikar, 2000, Dialog Intra-Religius, Yogyakarta: Kanisius, page 20

8 Zuhairi Misrawi, op.cit, page 178 
clusive attitude in religion carried out of its religious environment. Second, the erosion of local wisdom ${ }^{9}$ in the Java community that actually have values that are valuable to be practiced. Java community have wisdom in terms of tolerance or tepo sliro in all things, but because of the influence or penetration of other cultures, causing the values are eroded and replaced by other values that emphasizes violence than respect or appreciation for others. The roots of conflict actually comes from the assumption of the self-righteous. Such presumption is closing a dialogue that led to anti-tolerance attitude. This stance is at odds with the culture of Java, because according to Mulyana, the Javaneseness was basically a typical attitude toward life that transcends religious differences. ${ }^{10}$

The most essential thing in Javanese culture according to Sujatmo, is not the syncretism, but tantularism. This Tantularisme animates all aspects of Javanese culture that radiates through the nature of the following characteristics: religious, non doctrine/non-dogmatic, tolerant, accommodating, and optimistic. The fifth interactions reveal the nature of the pattern and nature of Javanese culture which are: first, believe in God as sangkan paraning dumadi and tan kena kinaya ngapa; second, patterned idealistic and believe in supranatural things; third, believe in destiny, let go, but not fatalistic; fourth, prefer the essence of the ritual and formal terms; fifth, put love as the basic foundation of human relationships; sixth, is Momot and non sectarian and respect the religion of others; seventh, convergent (fused) and respecting every truth from any source; and eighth did not consider that its confidence is the most correct. ${ }^{11}$

9 About the local wisdom, read Ni Wayan Sartini, "Menggali Nilai Kearifan Lokal Budaya Jawa Lewat Ungkapan (Bebasan, Saloka, dan Paribasa)". Jurnal Ilmiah Bahasa dan Sastra, Vol. V No. 1 April 2009

10 Mulyana, "Identitas Kejawen, Mengurai Benang Kusut", Jurnal Kebudayaan Jawa KEJAWEN, Vol. 1 No. 1 September 2005, page 8-10

11 Soetomo Siswo kartono dkk, 2014, Prosiding Kongres Kebudayaan Jawa 10-13 November 2014, Semarang: Yayasan Kanthil, page 569-570
More concrete of the Local wisdom of Java community can be found in Javanese proverb verbal expression associated with national values. First, lobok atine (loose heart) which illustratively reflects the concept of space, the arena, the nature (legawa, sincere). This expression is tailored to address the circumstances that is pluralistic, if not based on lobok atine attitude, it will be difficult to accept differences. Second, manis eseme, which can identificated to show the potential of compromising attitude, peaceful, harmonious, and the sign of a good start. Third, momot atine which means the patient or the patient. In the national context, this gives mentalistic contribution of nation to reflect the atmosphere of mutual understanding, ngemong, and promote togetherness. Fourth, dawa ususe, means very patient. This expression contribute to building the national spirit with the advanced nature of the patient. There are many other expressions of Java that have national values and useful in building religious harmony, such as ngendhaleni hawa nepsu, nglurug tanpa bala menang tanpa ngasorake, sugih tanpa bandha, digdaya tanpa aji, kengguh mring krincing dhinar, kengguh mring klubuking mina, kengguh mring klimising wentis kuning, and many more. ${ }^{12}$

When studied further by promoting local wisdom, that events does not need to be a conflict, all can be resolved by returning to the Javanese culture is valuable. As an example the case for instance the issue of funeral for minorities. If a return to the principle that human beings would die and return to the ground, then the question of where he wanted to be buried not be a problem. Lobok atine through local wisdom, then there will be resistance from residents. But what happens is the attitude of some people who did not receive the difference, a monopoly in the use of the cemetery by the majority and reject dialogue. This story happened in Brebes and Banyumas. Another example that is often come to the surface is a rejection of the construction of houses of worship for minorities. Possible cases in Banyumas

12 Abdullah dan Mulyati dalam Ibid, page 383-396 
can be used as an example. Christians HKBP Church intends to build in an area of South Purwokerto. After all requirements are met, appeared protests from residents. Forum for Religious Harmony (FKUB) Banyumas help by mediating between citizens and building committee, but not reached common ground. Therefore, it look for another location, and a similar incident happening again. Finally found the right location and there is no objection from local residents. Dialogue conducted by FKUB Banyumas from the first location HKBP church building to a third location happens to eighteen times.

Based on the data obtained, most cases show that people in the face of religious conflict does not promote the values of local wisdom in resolving conflicts. The value put forward is the selfishness of certain community groups that ultimately lead to conflict. A new dialog appears after years of conflict and the use of local wisdom limited to consultation only. This shows that the people of Java has lost its identity because it has been the abandonment of their culture of inter-religious. Conflict that occurred in Central Java would actually be more effective and would not even arise if the Javanese people do not lose their identity. The use of local wisdom in resolving religious conflicts Java is seen as more neutral than the use of other values that tends to favor one party. The problem is to build trust between people is not easy because this is related to culture. If violence is already a culture, then the dialogue will only be utopian. ${ }^{13}$

13 Culture in cultural development study is an 'ideational system' or 'ideas system', or the state of mind which support in specific behavior of some social group. Culture, one day will be on independent variable position when associated with the development of the economy of community. But, the culture itself could be changed by the public policy, so culture will change into dependent variable. The right place of culture is such which stated by Daniel Patrict Moynihan that 'The central conservative truth is that it is culture, not politics, that determines the success of a society. The central liberal truth is that politics can change a culture and save it from itself. Amri Marzali, "Ilmu Antropologi Terapan bagi Indonesia yang Sedang Membangun". Jurnal Antropologi Indonesia Vol. 68, 2002, Jakarta: Anthropology Department of FISIP UI Cooperate with Yayasan Obor Indonesia, page 95. Compare with Parsudi Supar-

\section{Juridical Constraints of Legal Development Based on Local Wisdom}

The state law that always be relied upon to resolve the conflict (internal and intra) religious people can not work properly. Under understand of legal centralism, the law of the country have a large role and impede our awareness of indigenous law, which is the manifestation of the worldview, social order and the ideal order that exists in the community. Even under legal thought as social engineering to make the state law is a comprehensive monolith in human settings so that local laws be pressed and marginalized in the realm of life. ${ }^{14}$ The problem is their juridical obstacles that cause local wisdom can not simply be used as a foundation for living in peace, and harmony.

The determination of the religious issue is a matter for central government not delegated to the regions (Article 7 (1) of Law No. 22 Year 1999 on Regional Government), creates problems in solving religious conflicts. Then, these laws removed/replaced by Law No. 23 Year 2014 on Regional Government, where the Article 10 letter $\mathrm{F}$ establishes religion as one affair into an absolute domain of the central government. Explanation of this article states that the term "religious affairs" as a certain religious holidays that apply nationally, give recognition to the existence of a religion, established a policy in the administration of religious life and others. Government area only given the opportunity to provide grants in the religious activities that are ceremonial.

When faced with the case of inter-religious conflict, there is a contradictory thing if the Regional Government Law is linked to other legislation, namely Law No. 7 Year 2012 on So-

lan, "Paradigma Naturalistik dalam Penelitian Pendidikan: Pendekatan Kwalitatif dan Penggunaannya". Antropologi Indonesia Vol. 21 No. 53, 2007, Jakarta: Anthropology Department of FISIP UI Cooperate with Yayasan Obor Indonesia; dan Jacob W. Ajawaila. "Orang Ambon dan Perubahan Kebudayaan". Jurnal Antropologi Indonesia, Vol. 61, 2000, Jakarta: Anthropology Department of FISIP UI Cooperate with Yayasan Obor Indonesia, page 21

14 Hermansyah, "Kejahatan Alienatif", Jurnal Dinamika Hukum, Vol. 8 No. 2 May 2008, Purwokerto: FH UNSOED, page 95 
cial Conflict Management jo Government Regulation No. 2 Year 2015 concerning the Implementation Regulations of Law No. 7 of 2012 in conjunction with the Regulation of the Minister of the Interior No. 42 Year 2015 on the Implementation Coordination of Social Conflict. Conflict between religious communities is basically a conflict inflicted on the understanding of a religion or a religious ritual by one of the parties is considered as less true or less right.

When referring to the Law on Local Government, these case clearly not a matter for Local Government, because of religious affairs is absolutely a matter for central government. Based on the explanation of Article 10 letter $f$, the domain of the central government on religious matters seem too mild. When referring to the Law of Social Conflict Handling, the conflict happen with any kind (including religion) reason or background, the local governments have an obligation to prevent, even overcome, by order of the central government or its own initiative. This is reflected in Article 6 paragraph (2), Article 10 and Article 11. This is one of the juridical obstacles in resolving the conflict between religious communities, because of discrepancies in the existing legislation.

Article 2 of Law No. 7 of 2012 contains several principles that reflect the maintaining of the conflict, namely the family, kebhinekatunggal-ikaan, justice, local wisdom, and participation. This principle is then fitted with the provisions of Article 41 which put forward the traditions and/or social institution recognized its existence in the settlement of the conflict, the results of which are recognized and have binding force for the groups involved in the conflict. If conflict resolution is unsuccessful, then the team formed by the government will action. This article is actually provide an opportunity for the region to develop policies or regulations that can be used as a base or backrest in the resolution of conflicts between religious groups based on local wisdom that belongs to the various regions in Indonesia

There are several examples where conflict religious backgrounds in the end did not find a satisfactory solution. For example, the conflict between the people and the church Yasmin Church in Bogor, the establishment of houses of worship (churches) in Jepara and the rejection of faiths cemetery in a common grave Brebes, Central Java. Settlement does not clear this would expand the existing conflict so that the root of the problem in the end be too vague and not easy anymore to an end. In such cases, what the central government's role in conflict resolution, none at all.

Therefore, in order that the area has no legal basis and force in the resolution of social conflicts religious background or religious conflicts, the Regional Government Law needs to be amended to give authority to the regions to resolve the existing problems in the area by using existing resources, including local wisdom that have. If this can be met, the government can synchronize with Law No. 7 Year 2012 on Social Conflict Management, the region has the authority to create regional regulations based local wisdom. Actually Law 7 of 2012 and its derivatives, also needs to be amended, given authority in the regions in social conflict resolution is only coordinative with the central government, in other words, there is no autonomy or initiatives for the region to resolve their own conflicts in the region.

If the juridical obstacles can be overcome, it is not impossible that Indonesia will have varied instrument of conflict resolution on the basis of local wisdom. Regional regulations will also be formed anthropological document of both the historical artifacts are priceless, as a cultural heritage. Indonesian society must relearn by digging the noble values of the nation's forgotten. ${ }^{15}$

\section{Closing}

\section{Conclusion}

There are three conclusions that can be given. First, the religious conflicts that exist in

15 Some good example of this, read Rini Fidiyani, "Kerukunan Umat Beragama di Indonesia (Belajar Keharomonisan dan Toleransi Umat Beragama di Desa Cikakak, Kec. Wangon, Kab. Banyumas)". Jurnal Dinamika Hukum, Vol. 13 No. 3 September 2013. Purwokerto: FH UNSOED. 
Central Java can be grouped into three categories, namely the conflict as a reflection of the dynamics of religious life; violations of freedom of religion; and intolerance committed by individuals, groups, communities or countries. The root problem is the behavior of the conflict in religious exclusivism that is not in place and the erosion of local wisdom in the community because it emphasizes the egoism.

Second, Central Java have an outstanding source of local wisdom. This local wisdom is a matter of legal development that can create harmony in society. Third, there are juridical constraints in the development of laws based on local wisdom, in the form of discrepancies between the law one with another, so there needs to be a strategic move to eliminate this juridical obstacles.

\section{Recommendation}

Recommendations can be given with regard to the two examined problems. First, there should be a breakthrough or discovery of new ways to preserve local wisdom in Central Java, both formal (education), and non-formal, instilled from an early age. Secondly, there should be synchronization of legislation that could give the authority to resolve conflicts between religious communities other than the manner prescribed by state law.

\section{Acknowledgement Letter}

Researchers would like to thank to: the Ministry of Research, Technology and Higher Education, which has funded this research; Chairman of the Institute for Research and Community Services Semarang State University; Dean of the Faculty of Law UNNES; informants in Semarang, Banyumas, Blora, Surakarta and Pekalongan with a will to take the time and opportunity to talk about the matter of nationality; and several students who helped this research well. May their good deeds get a reward from Almighty God.

\section{References}

Ajawaila, Jacob W. "Orang Ambon dan Perubahan Kebudayaan". Jurnal Antropologi Indonesia, Vol. 61, 2000. Jakarta: Anthropology Department of FISIP UI Cooperate with Yayasan Obor Indonesia;

Fidiyani, Rini. “Kerukunan Umat Beragama di Indonesia (Belajar Keharomonisan dan Toleransi Umat Beragama di Desa Cikakak, Kec. Wangon, Kab. Banyumas)". Jurnal Dinamika Hukum, Vol. 13 No. 3 September 2013. Purwokerto: FH UNSOED;

Hermansyah. "Kejahatan Alienatif", Jurnal Dinamika Hukum, Vol. 8 No. 2 May 2008, Purwokerto: FH UNSOED;

lgadrie, Syarif I. "Konflik Etnis di Ambon dan Sambas: Suatu Tinjauan Sosiologis". JurnalAntropologi Indonesia, Year XXXI. No. 58 2002. Jakarta: Anthropology Department of FISIP UI Cooperate with Yayasan Obor Indonesia;

Lemba Studi Sosial dan Agama (eLSA). 2014. Laporan Kebebasan Beragama dan Berkeyakinan di Jawa Tengah Tahun 2014. Semarang: eLSA;

Marzali, Amri. "Ilmu Antropologi Terapan bagi Indonesia yang Sedang Membangun". Jurnal Antropologi Indonesia Vol. 68, 2002. Jakarta: Anthropology Department of FISIP UI Cooperate with Yayasan Obor Indonesia;

Misrawi, Zuhairi. 2010. Al-Qur'an Kitab Toleransi, Tafsir Tematik Islam Rahmatan lil'Alamin. Jakarta: Pustaka Oasis;

Mulyana. "Identitas Kejawen, Mengurai Benang Kusut". Jurnal Kebudayaan Jawa KEJAWEN, Vol. 1 No. 1 September 2005;

Ni Wayan Sartini, “Menggali Nilai Kearifan Lokal Budaya Jawa Lewat Ungkapan (Bebasan, Saloka, dan Paribasa)". Jurnal Ilmiah Bahasa dan Sastra, Vol. V No. 1 April 2009;

Pannikar, Raimondo. 2000.Dialog Intra-Religius, Yogyakarta: Kanisius

Pelly, Usman. "Akar Kerusuhan Etnik di Indonesia: Suatu Kajian Awal Konflik dan DisintegrasiNasional di Era Reformasi". Jurnal Antropologi Indonesia, Year XXI No. 58 1999. Jakarta: Anthropology Department of FISIP UI Cooperate with Yayasan Obor Indonesia;

Robinson, Kathryn. "Ketegangan Antar Etnis, Orang Bugis dan Masalah 'Penjelasan". Jurnal Antropologi Indonesia, Year XXIV No. 63, September-December 2000. Ja- 
karta: Anthropology Department of FISIP UI Cooperate with Yayasan Obor Indonesia;

Sidharta, B.Arief. "Kajian Kefilsafatan tentang Negara Hukum". Jurnal Hukum "JENTE$R A^{\prime}, 3^{\text {rd }}$ Edition of $2^{\text {nd }}$ Year, November 2004;

Siswokartono, Soetomo dkk. 2014. Prosiding Kongres Kebudayaan Jawa 10-13 November 2014. Semarang: Yayasan Kanthil;

Suparlan, Parsudi, 1999, "Konflik Sosial dan Alternatif Pemecahannya." Jurnal Antropologi Indonesia, Year XXII No. 59 1999. Jakarta: Anthropology Department of FISIP UI Cooperate with Yayasan Obor Indonesia;

-.-.-.. "Mayarakat Majemuk dan Perawatannya". Jurnal Antropologi Indonesia, No. 63 Year XXIV, September-December, 2000. Jakarta: Anthropology Department of FISIP UI Cooperate with Yayasan Obor Indonesia;

"Paradigma Naturalistik dalam Penelitian Pendidikan: Pendekatan Kwalitatif dan Penggunaannya". Antropologi Indonesia, Vol. 21 No. 53, 2007. Jakarta: Anthropology Department of FISIP UI Cooperate with Yayasan Obor Indonesia;

Termorshuizen, Marjanne. "The Consept Rule of Law". Jurnal Hukum "JENTERA", $3^{\text {rd }}$ Edition of $2^{\text {nd }}$ Year, November 2004. 